Mieczysław Celestyn Paczkowski OFM

Uniwersytet Mikołaja Kopernika w Toruniu celestyn@umk.pl

ORCID: 0000-0002-4045-2314

DOI: http://dx.doi.org/10.12775/BPTh.2018.002
Biblica

et

Patristica

Thoruniensia

11 (2018) 1: 35-56

ISSN (print) 1689-5150

ISSN (online) 2450-7059

\title{
Zbawienie i jego geograficzny wymiar w patrystycznej interpretacji Ps 74(73),12
}

\section{Salvation and its geographical dimension in the patristic interpretation of the Ps 74(73):12}

Streszczenie. Ps 74(73),12 zainspirował całą serię rozważań o charakterze teologicznym, egzegetycznym i geograficznym, podjętych przez autorów wczesnochrześcijańskich. Przywoływanie tego wersetu w dziełach o różnym charakterze sugeruje, że odgrywał on niemałą rolę w starożytnej egzegezie chrześcijańskiej. Ojcowie Kościoła przede wszystkim nadawali Ps 74(73),12 znaczenie soteriologiczne. Po pewnym czasie pojawił się wyraźny wątek topograficzny, w którym wyrażenie: „[Bóg] pośrodku ziemi dokonał zbawienia" było odnośnikiem do Ziemi Świętej. To tam wypełniło się Boże dzieło odkupienia. $\mathrm{Z}$ tego powodu ten rejon stał się centrum świata. Ponadto Jerozolima nigdy nie utraciła swego szczególnego znaczenia, stąd pojawiają się motywy związane $\mathrm{z}$ historią, teologią i duchowością świętego miasta. W tej perspektywie Jerozolima jawiła się jako centrum ziemi. Pod wpływem zbiorowej wyobraźni chrześcijańskich pielgrzymów „pępkiem świata” było miejsce ukrzyżowania Zbawiciela - Golgota. W opisach starożytnych źródeł Ziemia Święta była postrzegana jako swoisty i unikalny przedmiot nie tylko refleksji teologicznej, lecz także historyczno-geograficznej.

\begin{abstract}
The Ps 74(73):12 inspired a series of exegetical, theological and geographical speculations in the early Christian writers. The various references in the reflections concerning the Ps 74(73) suggest that this verse played not indifferent role in the ancient Christian exegesis. The Fathers of the Church gave this psalmic verse the soteriological value. Subsequently, the topographic reading was instead profiled. "In the midst of the earth" indicated the Holy Land as a place for the fulfillment of God's saving work and it became the center of the world. In the Christianity the Holy City never lost its real reference and signification. On a biblical and theological basis the city of Jerusalem was considered the "navel of the earth”. In the collective imagination of Christian pilgrims the place of Golgotha (Calvary) was identified with the middle of the earth. In the various ancient descriptions, the Holy Land was treated as a very special, even unique, geographical-historical object.
\end{abstract}


Słowa kluczowe: Psalmy (księga); Ps 74(73),12; egzegeza patrystyczna; zbawienie; topografia biblijna; środek świata.

Keywords: Psalms (book of); Ps 74(73):12; Patristic exegesis; salvation; biblical topography; center of the world.

$\mathrm{W}$

starożytności chrześcijańskiej egzegeza Księgi Psalmów stała się uprzywilejowanym sposobem pogłębiania refleksji doktrynalnej i jej przekazywania. Tego typu lektura nie była jedyna. Pomijając rolę Psalmów w liturgii i pobożności chrześcijańskiej, należy zauważyć fakt, że w starożytnym Kościele popularna również była egzegeza o charakterze moralnym i duchowym. Pisarze starochrześcijańscy wykorzystywali Psalmy w dyskursie chrystologiczno-eklezjologicznym, jak o tym świadczy mistrzowska synteza św. Augustyna w Enarrationes in Psalmos. Na początku tej refleksji należy umieścić dzieło Orygenesa, który położył podwaliny pod egzegezę Psalmów. Stało się to mimo faktu, że większa część jego dorobku w tym względzie zaginęła.

Dla Ojców Kościoła Psalmy stanowiły syntezę Starego Testamentu. Ich lektura odbywała się w świetle dzieła zbawczego Chrystusa i wydarzeń Nowego Testamentu. Tak więc fakty ewangeliczne były jakby osnową chrześcijańskiej wizji Psalmów. Ponadto w przekonaniu Ojców Kościoła Psalmy odwoływały się do proroków, jak w przypadku Ps 74(73),12¹.

\section{Soteriologiczna wymowa Ps 74(73),12}

W egzegezie Kościoła teksty Psalmów przybierają znaczenie soteriologiczne, co ze szczególną wyrazistością widać w komentarzach patrystycznych do nich. Początki egzegezy Ps 74(73),12 mają charakter typologiczny. Starożytni pisarze Kościoła obficie korzystali z repertoriów skrypturystycznych, a niektóre wersety psalmodyczne były wielokrotnie przez nich analizowane. Dotyczyło to szczególnie głównych linii tematycznych o charakterze teologicznym. Ps 74 ukazywał, że zbawienie zawierało się w akcie stworzenia dokonanego przez Boga, zaś wybawienie narodu wybranego rozciąga się na cały rodzaj ludz$\mathrm{ki}^{2}$. Z tego względu Ps 74(73),12 mógł należeć do antologii testów biblijnych

1 Numeracja Psalmów wg BT; por. Pismo Święte Starego i Nowego Testamentu, Poznań 2000, s. 662.

2 Por. P.C. Bouteneff, Beginnings Ancient Christian Readings of the Biblical Creation narratives, s. 8. 
zwanych Testimonia. Poświadcza to zbiór przypisywany Cyprianowi z Kartaginy ${ }^{3}$. Ten werset psalmodyczny znajduje się pomiędzy Ps 44 a Mt 2,1-2. Sporadyczne cytaty czy aluzje autorów przednicejskich świadczą raczej o mniejszej popularności Ps 74(73),12 w Testimoniach niż możnaby się spodziewać.

Omawiany werset, lub tylko jego pierwszą część, stosowano przeciwko gnostykom, co poświadczają teksty pseudoireneuszowe ${ }^{4}$. Jednak sam biskup Lyonu, nakreślając ramy geograficzne rozpowszechnienia się chrześcijaństwa, mówi o Kościele założonym w środku ziemi ${ }^{5}$.

Hieronim poświadcza, że Orygenes był pierwszym, który skomentował cały Psałterz ${ }^{6}$. Być może Aleksandryjczyk czynił to w różny sposób: nie tylko poprzez komentarze, ale także homilie i odpowiedzi na szczegółowe kwestie (tzw. scholia). Komentarze Orygenesa to dziedzictwo, które trzeba odtwarzać, badając przede wszystkim tzw. catenae, jak również homilie Hieronima do Psalmów $^{7}$. Doktor aleksandryjski stwierdza, że „pośrodku ziemi Syn Człowieczy dokonał zbawienia, przebywając trzy dni i trzy noce w sercu ziemi. Jak się to wydaje, środkiem jest punkt centralny, ponieważ [świat] ma okrągły kształt"8. Adamancjusz nawiązuje do "znaku Jonasza” ", a umiejscawiając z kolei miejsce zbawienia w centrum świata odwołuje się do doskonałości przestrzennej wyrażonej przez okrągły kształt ${ }^{10}$.

3 Por. Testimonia ad Quirinum II, 29, s. 70.

4 Por. D. Jordan, Pseudo-Irenaeus Lugdunensis, Fragmenta varia, s. 189.

5 Por. Adversus haereses I,10,2. Być może chodzi o wspólnotę wiernych w Jerozolimie.

6 Por. Hieronim, Epistula 122, 20. Zainteresowanie Aleksandryjczyka tą księgą biblijną wzrastało jak wzbierający przypływ. Wskazuje na to nie tylko Hexapla, ale także fakt, że refleksja nad „Pieśniami Izraela” towarzyszyła wszystkim etapom jego życia. W okresie aleksandryjskim Orygenes opracował Komentarz do Psalmów 1-25. O wiele obszerniejszy jest komentarz, który powstał w Cezarei Nadmorskiej. Według Hieronima było to około 40 tomów.

7 Stanowią one po prostu tłumaczenie i adaptację analogicznego dzieła Orygenesa. Por. V. Peri, Omelie origeniane sui Salmi.

8 Selecta in Psalmos (Ps LXXIII, 12), PG 12, kol. 1532 B.

9 Por. In Jonam I,1; I,3. Tłumacz wielkiego Aleksandryjczyka, jakim był Hieronim ze Strydonu, stwierdza, że odwoływanie się w tym przypadu do praw alegorii może wystawić niedoświadczonego komentatora na niebezpieczeństwo błędu.

10 Koło to nie tylko najprostsza, ale także najdoskonalsza figura geometryczna. Jest obrazowym przedstawieniem pełni i doskonałości. Pisarze chrześcijańscy nie pomijają jednak osi, która pozostaje nieporuszona i dokoła której kręci się koło. Ten symbol wyobrażał więc bieg czasu i historię zbawienia, a postać Chrystusa, będąca jakby jego nieporuszającą się osią, stanowi jego środek. Por. D. Forstner, Świat symboliki chrześcijańskiej, s. 57. 
Szczególnego znaczenia nabiera świadectwo Dionizego Bar Salibi, który przypomina błędy Gajusza ${ }^{11}$. Odnośnie do Ap 9,2.3 twierdził on, że prawi są prześladowani „pośrodku ziemi”, lecz Bóg dochowuje wiary w kwestii zbawienia (por. $2 \mathrm{Tm} 3,12.13^{12}$. Bar Salibi cytuje Pismo Święte z wielką swobodą, przywołując tekst Peszitty i Syrohexapli, jeśli chodzi o Stary Testament.

Św. Hieronim wspomina o traktacie atanazjańskim De titulis Psalmorum. Dzieło to jednak jest pióra Hezychiusza z Jerozolimy ${ }^{13}$. Odkryć tam jednak można wątki antyariańskie, będące echem pewnego typu interpretacji. „Bogiem jest Twoje Słowo, nasz Król przed wiekami, który został ukrzyżowany, aby utwierdzić Twój lud w wierze"14.

Metropolita Cezarei, Euzebiusz starał się sprzyjać arianom, lecz w sposób na poły ukryty ${ }^{15}$. Zadowolil się on lekturą soteriologiczną Ps $74^{16}$.

[Psalmista] kontynuuje opowiadanie o opatrzności i przedstawia wielkie dzieła mocy Bożej, wyrażając się w odpowiedni sposób przez [formuły] pełne szacunku... [I] mówi: Nawet, jeśli coś urzeczywistniło się w ten sposób, jesteśmy jednak przekonani, że Ty jesteś Bogiem, którego uznajemy także jako naszego Króla, kierującego wszystkim przez władczy i Boży osąd, dla zbawienia wszystkich ludzi. „Bóg jest naszym królem, pośrodku ziemi dokonał zbawienia” (Ps 74 [73],12). Tak więc, nawet jeśli dopuściłeś, aby dokonały się takie rzeczy [w celu zbawienia] w jednym zakątku ziemi z powodu tych, którzy go zamieszkiwali, jednak jesteśmy przekonani, że udzielisz zbawienia ludziom, którzy zamieszkują całą ziemię, wzbudzając Zbawcę dla wszystkich ludzi, twojego Chrystusa. Wydaje mi się, że za pomocą tego jednego wersetu jakby udaje się rozwiać... wątpliwości. Stanie się zbawienie, którego Bóg „dokona pośrodku ziemi”. Jak zwykle tutaj proroctwo wyraża się za pomocą czasu przeszłego, zamiast określenia przyszłości ${ }^{17}$.

11 Odrzucał on Ap i pisma Janowe, przez co spotkał się ze zdecydowaną reakcją Hipolita Rzymskiego, por. E. Prinzivalli, Gaio (e Alogi), kol. 2029-2030.

12 Zob. I. Sedlacek, Dionysius bar Salibi. In Apocalypsim, s. 8-10.

13 Por. J. Quasten, Patrologia, t. 2, s. 41.

14 De titulis Psalmorum (LXXIII,23-24), PG 27, 953 C. Pisząc przeciwko arianom, biskup Aleksandrii zaznacza, że Chrystus „w ludzkiej naturze chciał utwierdzić królestwo na Syjonie, aby [wszystkich] wybawić z grzechu”; Contra Arianos II,52, PG 26, kol. 257 C.

15 Objęcie stolicy biskupiej w Cezarei przez Akacjusza uczyniło z metropolii palestyńskiej punkt oparcia dla zwolenników arianizmu. Odnośnie do niektórych dzieł Akacjusza zob. Hieronim, Epistula 119,6.

16 Nie robi żadnego odniesienia do topografii, co było bardzo częste u autorów palestyńskich.

17 In Psalmos III (73,12-17), PG 23, 861 B-C. 
Cyryl Jerozolimski opowiadał się przeciwko twierdzeniom, że zbawienie dokonało się w sferze niewidzialnej, w kategoriach neoplatońskich. Był to argument szeroko dyskutowany przez autorów tamtego okresu. Przy omawianiu historii Zbawienia Cyryl Jerozolimski zwracał uwagę na "prymat miejsca” ukazany w świętych księgach i na tej podstawie formułuje zasadę teologiczną „świętości Jerozolimy” ${ }^{18}$. W „geografii wiary” miasto święte stanowi najważniejszy punkt ${ }^{19}$.

Postacie Euzebiusza z Cezarei i Cyryla Jerozolimskiego, mimo istotnych różnic, świadczą o ciągłości pewnego sposobu myślenia i pojmowania teologii oraz specyficznego ujęcia realiów geograficznych Ziemi Świętej w rozważaniach egzegetycznych i doktrynalnych. Nie chodzi tutaj o rewolucyjne zmiany czy innowacje, ale raczej odpowiedzi na nowe problemy.

Do drugiej generacji arian należał Eunomiusz - biskup Kyziku. W kontekście kontynuowania z nim polemiki Grzegorz z Nyssy nawiązuje do refleksji swego brata - Bazylego ${ }^{20}$. Przywołuje pierwszą część Ps 74(73),12, by wskazać na pełne bóstwo Chrystusa ${ }^{21}$. Grzegorz z Nazjanzu odwołuje się do tytułów chrystologicznych, ukazujących wielkość Syna Bożego. Cytuje Hi 3,8 i nazywa Zbawcę „królującym nad wodami”22.

Nysseńczyk podejmuje także dyskusje z Apolinarym z Laodycei, który sprowokowany przez arian, odmawiających pełnego bóstwa Chrystusowi, stworzył koncepcję osoby Zbawiciela, poważnie naruszającą jego człowieczeństwo ${ }^{23}$. Także i w tym przypadku Grzegorz kontynuowal polemikę swego brata Bazylego. Refleksja egzegetyczna i teologiczna Nysseńczyka osnuta na Ps 74(73),12 ${ }^{24}$ miała na celu udowodnienie pełnego człowieczeństwa Zbawiciela.

18 Cyryl Jerozolimski cytuje Ps 74,12 w Catechesis XIII,28, PG 33, 805 B.

19 Cyryl kładł nacisk na fakt, że historia zbawienia dokonała się w miejscach dobrze znanych słuchaczom jego kazań, por. Catechesis II,7; III,7; XVI,4; XVII,13; XVIII,33.

20 W Adversus Eunomium powstałym w latach 363-365, Bazyli oskarża Eunomiusza nie tylko o herezję, ale i bezprawne zastępowanie terminologii biblijnej słownictwem filozoficznym.

21 Por. Contra Eunomium I, 669; II, 460-461, s. 218; 361.

22 Por. Oratio 39, 16, s. 18 (aluzje do Ps 74,12-14).

23 Na temat doktryny apolinarystycznej por. A. Grillmeier, Christ in Christian Tradition, s. 220-233; J.N.D. Kelly, Początki doktryny chrześcijańskiej, s. 217-221; Ch. A. Beeley, The Early Christological Controversy: Apollinarius, Diodore, and Gregory Nazianzen, s. 378-395; M. Pyc, Apolinaryzm w kontekście sporu o integralność człowieczeństwa Jezusa Chrystusa, s. 5-16.

24 „Człowiek zostal stworzony na końcu, podczas gdy Pan, jest «królem przed wiekami»”; Antirrheticus adversus Apollinarem, ed. F. Mueller, s. 134. Zob. tenże De hominis opificio II, 132-133. 
Ten, który jest „królem przed wiekami”25, narodził się, gdy aniołowie oznajmili, że [oto] nadeszła wielka radość dla całego narodu, gdy narodził się Zbawiciel. Pismo [Święte] mówi [o tym] w odpowiedni sposób: „Ten, który jest Mesjaszem, Panem” (por. Łk 2,11), a według [słów] Gabriela, Duch Święty na Dziewicę, a moc Najwyższego ją osłoni ${ }^{26}$.

Ambroży przedstawia wcielenie Syna Bożego i jego narodziny przed wiekami. „Dowiedzieliśmy się, że Syn Boży «stał się człowiekiem» i odnosimy to do Jego człowieczeństwa. Według ciała stał się potomkiem Dawida, ale jako «Bóg przed wiekami», narodził się z Boga"27. Wyrażenie zaczerpnięte z wyznania wiary i tekstu biblijnego wskazuje na tajemnicę wymykającą się zdolnościom poznawczym człowieka ${ }^{28}$.

Hilary z Poitiers odwoływał się na konkretnej, historycznej sytuacji, w której powstał określony Psalm, ponieważ trzeba mieć świadomość, kto wypowiada natchnione słowa, albo do kogo są one skierowane. Galijski biskup stosuje zasady egzegezy prozopograficznej ${ }^{29}$. Wzmianka o Ps $74(73), 12^{30}$ u biskupa Poitiers nawiązuje do śmierci krzyżowej Zbawiciela:

Pośrodku globu ziemskiego, gdzie nasz Pan został umęczony, zbawiając nas (in medio... orbis terrae loco, in quo Dominus salutem nobis operans passus est), [Bóg] uczynił znaki i cuda: w godzinach jego ukrzyżowania słońce ukryło się, ziemia zadrżała, pękały skały, groby się otwierały i powstawali z nich umarli ${ }^{31}$.

25 Bóstwo określa „godność królewską. [Pismo bowiem] mówi: «Bóg od początku jest moim królem» (Ps 74[73],12). Ale także Syn Króla, który ma wszystko, co należy do Ojca, sam nazywany jest Królem”. Ad Eustathium de sancta Trinitate, Gregorii Nysseni Opera 3,1, s. 15.

26 Antirrheticus adversus Apollinarem, Gregorii Nysseni Opera, t. 3/1, s. 225.

27 De fide III, 4, 34, ed. C. Moreschini, Sant'Ambrogio, La fede, s. 208-209. Zenon z Werony mówił o bóstwie Chrystusa, o którym świadczy fragment Rdz 1,27 i Ps 74,12; 92, 2; por. Tractatus II,5.

28 Dla Ambrożego z Mediolanu fakty zbawcze urzeczywistniają się w chrzcie i Eucharystii. Szczególnie te sakramenty uważa on za „miejsca” dokonywania się zbawienia. Chrystus cierpiał za wszystkich ludzi i w Nim zostali oni odkupioni i zbawieni; por. De sacramentis II,2,6.

29 Por. M.-J. Rondeau, Les commentaires patristiques du Psautier III - Ve siècles, t. 2, s. $333-353$.

30 Oznaczenie odwołujące do Tractatus Mysteriorium I, 3 jest błędne, por. Biblia patristica. Index des citations et allusions bibliques dans la littérature patristique, Paris 1995, s. 124.

31 Tractatus super Psalmos 134,19, ed. A. Zingerle, CSEL 22, s. 706. 
Augustyn z Hippony analizuje Ps 74(73),12 w Enarrationes in Psalmos oraz w De civitate Dei. Komentarze do Psalmów posiadają jednak dosyć jednolity charakter $^{32}$, co zbliża je do drugiego z przywołanych dzieł.

W Enarrationes Augustyn cytuje pierwszą część wersetu Ps 74(73),12 i pyta:

Bóg zatem, Król nasz przed wiekami, czego dokonał? „Dokonał zbawienia w środku ziemi" - a ja ciągle wołam opuszczony. Oto dopełnia zbawienia w środku ziemi, a ja zostałem ziemią. Asaf zrozumiał dobrze, ponieważ [napisano] „zrozumienie Asafa". Dlaczego bowiem te rzeczy albo jakiego zbawienia dokonał Chrystus, jeśli nie tego, żeby ludzie nauczyli się pragnąć rzeczy wiecznych, a nie tkwić nieustannie w doczesnych. „Dokonał zbawienia w środku ziemi” (Ps 74 [73],12). Kiedy tak wołamy „Bóg zaś, Król nasz przed wiekami, dokonał zbawienia w środku ziemi”, my natomiast śpimy. Poganie już czuwają, my natomiast chrapiemy, jakby nas Bóg opuścił, a my szalejemy we śnie. „Dokonał zbawienia w środku ziemi”33.

Asaf jest przewodnikiem dla egzegety chrześcijańskiego ${ }^{34}$. Kolejny werset Psalmu ukazuje, że chrzest uwalnia od grzechów. „Jakiego zbawienia «dokonał Bóg w środku ziemi»? Nasze ziemskie wybawienie zostało zniweczone. Czego dokonał? Co obiecywał"? 35 .

Przy rozważaniach następnych wersetów Ps 74[73],12 staje się jakby motywem wiodącym. Hippończyk wskazuje na pokonanie „smoka” (szatana) i grzechu. Doctor gratiae opisuje w szerokiej perspektywie dzieło zbawienia: od Rdz 3,15, po epizod z Wj 32,1-2 i Dz 10,1336. Moc diabła zostaje zniweczona, a zwycięstwo Chrystusa jest zupełne. Swoje rozważania konkluduje następująco:

Jest zrozumiałe, że to wszystko, co widzi się obecnie na świecie, kiedy dokonał Bóg zbawienia w środku ziemi, jeszcze nie zaistniało, kiedy słowa te zostały wypowiedziane. Oto tu zostały przepowiedziane, teraz ukazuje się niejako spełnione, a głupi nadal powiada w sercu swoim: „Nie ma Boga” (Ps 13,1) ${ }^{37}$.

32 Hippończyk wskazywał na związek Chrystusa z Dawidem, który Go zapowiadał. Zob. H. Müller, Enarrationes in Psalmos, Philologische Aspekte, s. 806-807.

33 Enarrationes in Ps 73,14, PL 36, kol. 937, PSP 39, s. 315.

34 Augustyn postrazegał Psalmy jako „proroctwo”. Por. A.-M. La Bonnardiere (éd.), Saint Augustin et la Bible, s. 296; V. Fabre, La Prophétie des Psaumes selon saint Augustin. A propos de Ps 1,1, s. 546-547.

35 Enarratio in Ps 73,15, PL 36, kol. 937, PSP 39, s. 315.

36 Por. odnośniki w PSP 39, s. 316-317.

37 Enarratio in Ps 73,20, PL 36, kol. 941, PSP 39, s. 374. 
Pytając o to, „w jaki sposób ustanowił krańce ziemi ${ }^{38}$ Ten, który «dokonał zbawienia w środku ziemi»", Augustyn odpowiada słowami Ef 2,8-10. Postępujący na drodze dobra człowiek, osiąga zbawienie tylko dzięki łasce, nie zaś za pośrednictwem własnych wysiłków ${ }^{39}$. Potrzeba łaski Bożej u biskupa Hippony logicznie wiąże się z dokonanym przez Jezusa Chrystusa odkupieniem ${ }^{40}$. W krótkim komentarzu do innego wersetu psalmodycznego Hippończyk łączy Ps 74(73), 12 z J 14,6, Iz 11,1. „Co na to powiesz, manichejczyku, który twierdzisz, że Zbawiciel nie miał ciała? Oto Prawda, Zbawiciel narodził się «z ziemi», to znaczy Maryi"41. Taki sposób interpretacji był nie tylko bronią w walce z manichejczykami ${ }^{42}$, ale także skutecznie służył katechizacji.

Zwracanie uwagi na tego typu kwestie wskazuje na jego troskę o szerokie grono słuchaczy. Byli oni bardzo różni, ale nieustannie narażeni na kontakt w błędnymi naukami i pozostałościami pogaństwa, W De civitate Dei Hippończyk wskazuje na sąd Bożej sprawiedliwości i wyjaśnia:

Czynienie sądu i sprawiedliwości „z Boga jest” $(1 \mathrm{~J} \text { 4,7 })^{43}$. Cóż to znaczy „w środku ziemi”? Czyż ci, co na krańcach ziemi mieszkają, już nie mają czynić sądu i sprawiedliwości? Któż by mógł coś podobnego powiedzieć? A więc dlaczego dodane jest „w środku ziemi”? Gdyby tego dodatku nie było i tylko by było powiedziane "czynić sąd i sprawiedliwość" 44 - to by to przykazanie wyraźniej dotyczyło i mieszkańców wśród lądów i nad morzem mieszkających ${ }^{45}$.

Ta opinia, wskazująca na powszechność sądu w sensie geograficznym, zostaje uzupełniona o szczegółowsze wskazania w wykładzie na temat jedności duszy i ciała. Rozumna dusza i śmiertelne ciało to integralne elementy, tworzące harmonijną całość. Jednak, zdaniem biskupa Hippony, dusza jest zamknięta w powłoce ziemskiej, to jest w ciele. Przy końcu czasów cały człowiek będzie poddany sądowi, zgodnie z słowami Ps 74(73),12.

38 Hippończyk podaje interpretację chrystologiczną „krańców ziemi” w Enarratio in Ps 108,32 .

39 Augustyn wielokrotnie wskazywał na darmowość łaski i na jej charakter uprzedzający uczynki. Por. np. Enarratio in Ps 31 (2), 7.

40 Por. De libero arbitrio XIII, 37.

41 Enarratio in Ps 84, 13 (12), PL 37, kol. 1079, PSP 39, s. 315.

42 Autor De civitate Dei znał manichejską wersję antytezy „Jerozolima - Babilonia”. Przeciwne rzeczywistości obu miast rozpatruje na różnych płaszczyznach.

43 Analogicznie do miłości.

44 „Bóg jest tak sprawiedliwy, że sądzi bez miłosierdzia tego, kto nie okazuje miłosierdzia" (por. Jk 2,13); Enarratio in Ps 111, 3; 5.

45 De civitate Dei XVII, 4, 8, PL 41, kol. 531, Święty Augustyn, Państwo Boże, s. 654. 
Otóż mnie się to tak zdaje, żeby ktoś nie myślał, że po skończonym tym życiu, które w naszym ciele przepędzamy, będzie jeszcze czas na czynienie sądu i sprawiedliwości, czego się za życia ciała nie czyniło, i że w taki sposób uniknie się sądu Bożego, przeto dodane jest „w środku ziemi”, to znaczy: „dopóki kto w ciele żyje”, w tym bowiem życiu każdy swą ziemię nosi wszędy ze sobą ${ }^{46}$. Po śmierci zabiera ją ziemia wspólna, a przy zmartwychwstaniu znów ma ją oddać. Stąd „w środku ziemi”, to jest: dopóki dusza nasza w tym ziemskim ciele jest zamknięta ${ }^{47}$, trzeba czynić sąd i sprawiedliwość, a to nam się na przyszłość przyda ${ }^{48}$.

Określenie „w środku ziemi” św. Augustyn rozumie jako aspekt jedności i odpowiedzialności całego człowieka, składającego się z duszy i ciała ${ }^{49}$.

Sąd obejmie wszystkich ludzi. „[Bóg] nie pominie w sądzie swym żadnej części ziemi... Schyłek człowieka to krańce życia"50. Hippończyk wskazuje na napominanie i karcenie grzesznika jako na zabiegi mające doprowadzić go do nawrócenia. To doświadczenie ludzkie przyjmuje nazwę „sądu tajemnego”. To antycypacja tak zwanego „sądu jawnego przy końcu świata ${ }^{51}$. W nawiązaniu do Mt 10,22 Augustyn kontynuuje: „Kto wytrwale sąd czyni i sprawiedliwość ${ }^{2}$ «w środku ziemi», nie będzie potępiony, gdy sądzone będą krańce ziemi" 53 .

Wyrażenia stosowane przez Psalmistę wzbudzają w wiernych cześć i uwielbienie dla Boga oraz zesłanego wiekami na świat Syna Bożego. „Przez słowa «Bóg nasz» rozumiemy Pana Jezusa ${ }^{54}$, który istniał przed wiekami i przez Niego wszystko się stało, a uczynił nasze zbawienie «w środku ziemi», gdy «Słowo

46 Człowiek przez swoje ciało jest związany ze światem materialnym (ziemia).

47 „[Człowiek] dopóki przebywa w tym ciele poddanym śmierci, «pielgrzymuje do Pana», idzie "przez wiarę, a nie przez widzenie» (2 Kor 5,6.7)"; De civitate Dei XIX,14, PL 41, kol. 642.

48 De civitate Dei XVII, 4, 8, PL 41, kol. 531, Święty Augustyn, Państwo Boże, s. 654.

49 Por. De civitate Dei XVII, $4,8$.

50 De civitate Dei XVII, 4, 9, PL 41, kol. 532, Święty Augustyn, Państwo Boże, s. 655.

51 Por. Sermo 397, 2, 2; Enarrationes in Ps 9, 1; 7, 13.

52 Na podstawie $\mathrm{Rz}$ 13, 8 Augustyn określa sprawiedliwość jako cnotę, zgodnie z którą dajemy każdemu to, co mu się należy, nikomu nie będąc nic winnymi, a wszystkich miłując; por. Enarratio in Ps 83,11 .

53 De civitate Dei XVII, 4, 9, PL 41, kol. 532, Święty Augustyn, Państwo Boże, s. 655.

54 Augustyn przedstawia Chrystusa jako króla chwały, Pana mocnego i potężnego, wznoszącego się ponad wszelkie istnienie; por. Enarratio in Ps 23, 10. 
ciałem się stało» (J 1,14) $)^{55}$ i zamieszkało w ciele ziemskim" "56. Doktor Kościoła łączy troskę Boga o zbawienia ludzkości z faktem wcielenia. Czyni to w przekonaniu, że wierni, mimo ludzkich ograniczeń i słabości, zdołają przyswoić sobie chociaż odrobinę prawdy odnoszącej się do tajemnicy Bóstwa Zbawiciela i Jego stawania się człowiekiem.

Quodvultdeus kieruje przeciwko Żydom oskarżenie o odrzucenie zbawienia. „Nie uznaliście Zbawiciela, który «dokonał zbawienia pośrodku waszej ziemi», a pogrążeni w złości mówiliście: «Ty sam o sobie wydajesz świadectwo. Świadectwo Twoje nie jest prawdziwe» (J 8,13)" 57 . Z osobą Zbawcy łączą się wzmianki odnoszące się do świętego miasta Jerozolimy ${ }^{58}$.

Także Piotr Chryzolog analizował kwestię zbawienia ludu izraelskiego. Czyni to, nawiązując do uzdrowienia teściowej św. Piotra Apostoła. Kaznodzieja od razu wskazuje na sens metaforyczny i typologiczny.

[Zbawiciel] ujrzał synagogę leżącą w mrokach swej niewiary, przygniecioną brzemieniem swoich grzechów, gorączkującą z powodu swych wad aż do utraty świadomości, To, dlatego wziął ją za rękę, aby nie tylko przez słowo, ale także za pomocą rąk dokonuje zbawienia ludu izraelskiego. Posłuchaj natchnionego autora [dosł. proroka]: «Bóg jest naszym królem od zmierzchłych czasów, pośrodku ziemi dokonał zbawienia» (Ps 74 [73],12). „Ujął ją za rękę”, aby w ten sposób została oczyszczona z krwi proroków, zanim przyjmie posługę kościelną ${ }^{59}$.

Werset psalmodyczny stanowi swego rodzaju zwornik całej refleksji osnutej na kanwie ewangelicznego uzdrowienia. W ujęciu typologicznym postać teściowej reprezentuje tę część wiernych, którzy przyjęli Chrystusa i stanowią Kościół z obrzezanych (Ecclesia ex circumcisione). Służą Mu, wypełniając dobre dzieła.

Arnobiusz Młodszy to autor polemizujący z doktryną augustyńską o łasce. Pozostawił on komentarz do Psałterza o charakterze alegorycznym. Pisarz ten wyjaśnia sporadycznie „literę” tekstu psalmodycznego i czyni to wyłącznie, jeśli są ku temu jakieś specjalne powody ${ }^{60}$. Zakłada przy tym, że jego czytelnicy

\footnotetext{
55 Por. Enarratio in Ps 70 (2),10.

56 De civitate Dei XVII, 4, 8, PL 41, kol. 531-532, Święty Augustyn, Państwo Boże, s. 654 .

57 Quodvultdeus, Sermo 4 (Contra Iudaeos, paganos et Arianos), 11, ed. R. Braun, CCL 60, Tornhout 1976, s. 372.

58 Por. Liber promissionum et praedictorum Dei II,20,37; 22,42; 37,85.

59 Sermo XVIII,7, ed. G. Banterle, Opere di San Pietro Crisologo, t. 1, s. 156.

60 Por. S. Leanza, L’esegesi di Arnobio il giovane al libro dei Salmi, s. 229.
} 
znają sens dosłowny. Tego typu przekonanie daje się zauważyć odnośnie do Ps 74(73),12. „«Przed wiekami» jest ten, który uczynił wieki i «dokonał zbawienia w środku ziemi», w naszym Panu Jezusie Chrystusie"61. Cytat z Ps 75(74),5-6 to słowa Zbawiciela skierowane do nieprawych i grzeszników ${ }^{62}$.

Interpretacja Ps $74^{63}$ przez Teodoreta z Cyrru, podobnie jak innych natchnionych pieśni przypisywanych Asafowi ${ }^{64}$, charakteryzuje się oszczędnością i unikaniem nadmiaru cytatów biblijnych. Biskup Cyrru wskazuje: „Troskę, którą masz wobec nas, uczyniłeś wiadomą wobec wszystkich. To «w środku ziemi dokonałeś zbawienia», by to było dla wszystkich widoczne" 65 . Ten egzegeta był przekonany, że „świadectwo tekstu literackiego [Psalmów] jest wystarczające, by tych, którzy chcą odnaleźć prawdę prowadzić za pomocą komentarza"66. Czytelnicy wiedzieli więc, że autor czuł się swobodniej niż przy innych dziełach egzegetycznych, jak np. Komentarza do Iz.

Komentarz Kasjodora do Psalmów to jego najobszerniejsze dzieło egzegetyczne o zwartej strukturze. Słychać w nim echa interpretacji św. Augustyna, szczególnie poprzez odwołanie się do wątków soteriologicznych.

Przez ducha proroczego ${ }^{67}$ [Asaf] zapowiada, że przyjdzie Chrystus, wyliczając za pomocą [słów] modlitwy, jakie cuda uczyni na niebie i ziemi... Ponieważ miało być powiedziane o jego wcieleniu ${ }^{68}$, by nikt nie sądził, że zaczął [On] istnieć w czasie, jest poświadczone, iż od początku świata był już królem, jak sam powiedział

61 Commentarii in Ps 74, s. 111.

62 Widać tu wyraźne nawiązanie do św. Augustyna; zob. Enarratio in Ps 74, 14.

63 Homilia Jana Chryzostoma o tym Ps nie zachowała się. Na temat egzegezy biskupa Cyru o Ps 74(73) zob. M.C. Paczkowski, Gerusalemme - „ombelico del mondo” nella tradizione cristana antica, s. 191-192.

64 Komentarz Teodoreta zachował się w kompletnych manuskryptach, nie jest więc rozproszony w zbiorach zwanych catenae. Edycji tekstu dokonał J.L. Schulze w XVIII w. Tekst ten został przedrukowany przez J.-P. Migne’a w PG 80, kol. 857-1998. Biskup Cyru wzmiankuje, że skomentował „wszystkich proroków, psałterz i Apostoła [Pawła]”; Epistula 82, s. 202.

65 Teodoret z Cyru, Interpretatio in Ps. 73,8 (12), PG 80, 1480 B, por. R. Hill, Theodoret of Cyrus, Commentary on the Psalms 73-150, t. 2, s. 14.

66 Interpretatio in Ps. [praefatio 4], PG 80, 861 C, por. R. Hill, Theodoret of Cyrus, Commentary on the Psalms 1-72, t. 1, s. 41.

67 Dla Wigiliusza $\mathrm{z}$ Thapsus Ps 74,12 to prorocka zapowiedź zbawienia, dokonanego przez wcielenie; por. Wigiliusz (pseudo), Opus contra Varimadum Arianum I,60; III,8.

68 Już Atanazy podkreślał, że „Księga Psalmów po stwierdzeniu, że stanie się On [Chrystus] człowiekiem, w sposób naturalny ukazuje Go również jako cierpiącego w ciele”; Epistola ad Marcellinum 7, PG 27, 15 C, por. św. Atanazy, List do Marcelina o interpretacji Psalmów, s. 313. 
w Ewangelii: «Ja się na to narodziłem» (J 18,37)... „Dokonał zbawienia w środku ziemi”. Chociaż z tego i z dokonanych cudów można wnioskować, że przed ludźmi ukazało się Jego dzieło, jednak to pojmujemy lepiej z faktu zbawienia dusz, co jest najważniejszym celem przepowiadania. „Pośrodku ziemi”: dotyczy [to] wszystkich poszczególnych narodów, którym nadano określenie „ziem”. [Taka] figura [retoryczna] zwie się metonimią ${ }^{69}$.

W refleksjach Kalabryjczyka nie brakowało elementów oryginalnych ${ }^{70}$. Wtedy jednak ugruntowała się refleksja o znamionach geograficznych. To, co wcześniej było zaledwie sygnalizowane lub pojawiało się $\mathrm{u}$ pojedynczych autorów, stało się standardem dla interpretacji Ps 74(73),12.

\section{Kontekst geograficzny egzegezy Ps 74(73),12}

Konkretność zbawienia dokonanego z Bożej inicjatywy jest związana z terytorialnością. Wcielenie nie dotyczyło sfery mitologii, ale historii. Dla chrześcijan aspekt terytorialny miał zupełnie inne znaczenie niż w judaizmie. Nie należy zapominać, że koncepcja Jerozolimy jako centrum świata wyraźnie rozwinęła się w literaturze rabinistycznej, która lokalizowała środek ziemi na Syjonie ${ }^{71}$. Według tych koncepcji przez „górę Pańską"72 przebiega oś świata (axis mundi), a miejsce takie jest zawsze punktem przecięcia się trzech sfer kosmicznych: nieba, ziemi i piekieł oraz zetknięcia się świata widzialnego z niewidzialnym. Syjon stal się wzniesieniem sięgającym nawet niewidzialnych wyżyn ponad niebem ${ }^{73}$. Analogiczne idee są dosyć wcześnie poświadczone na Bliskim Wschodzie i to w cywilizacjach starszych od izraelskiej: egipskiej i mezopotamskiej. Samary-

69 Expositio Ps 74,11, PL 70, 530 C-D („quando per id quod continet, id quod continetur ostendit”). Por. M.C. Paczkowski, Gerusalemme - „ombelico del mondo”, s. 193.

70 Jego interpretacja Ps $60 \mathrm{z}$ nawiązaniem do „środka ziemi” ma charakter typologiczny.

71 Powoływano się na Ps 74(73),12, ale także inne teksty (Ez 5,5; 38,12). Por. np. F. Böhl, Über das Verhältnis von Shetija-Stein und Nabel del Welt in der Kosmogonie der Rabbinen, s. 77-90.

72 W wielu mitologiach mówi się o "górze świętej” i uważa się ją za centrum świata, miejsce, w którym spotyka się niebo z ziemią. Na niej wznoszono świątynie i twierdze oraz święte miasta.

73 Por. M. Gruna-Sulisz, Świątynia jerozolimska jako kosmogoniczne centrum i model wszechświata, s. 363; M.C. Paczkowski, Gerusalemme - „ombelico del mondo”, s. 165-166. 
tanie wskazywali na Górę Garizim jako centrum świata, a Grecy na Delfy ${ }^{74}$. Podobnego miejsca nie brakowało w Rzymie ${ }^{75}$.

W chrześcijaństwie geografia zbawienia miała ważną rolę, bo zbawienie dokonywało się w konkretnej sferze zewnętrznej i materialnej ${ }^{76}$. Ps 74(73),12 był jednym z tekstów ogniskujących aspekty geograficzne. Położenie w „środku świata" to główny element teologii Syjonu w ujęciu chrześcijańskim ${ }^{77}$, czego preludium stanowiła tradycja apokryficzna ${ }^{78}$.

Chociaż z tendencją topograficzną w egzegezie Psałterza ma się do czynienie w szerszej skali dopiero od $\mathrm{V}$ wieku, nie brak jednak prekursorów tego typu interpretacji. Widać to już w krótkiej dygresji Atanazego. Metropolita Egiptu w interpretacji Psałterza preferował sens alegoryczno - typologiczny ${ }^{79}$, w odróżnieniu od znaczenia bardziej dosłownego, które uwydatnia w swoich pismach polemiczno - dogmatycznych ${ }^{80}$. To być może z tego powodu stwierdza, że ponieważ „«Bóg pośrodku ziemi dokonał zbawienia», to $\mathrm{z}$ tego powodu Jerozolima nazywana jest "pępkiem świata»" 81 .

Inni autorzy sięgali do argumentacji biblijnej, wskazując, że wszystkie najważniejsze wydarzenia, jak Wcielenie, Chrzest Chrystusa i Zesłanie Ducha

74 Odnośnie do Delf jako „pępka świata” por. np. Hezychiusz, Lexicon, tau 1134.

75 Niedaleko łuku triumfalnego Septymiusza Sewera znajduje się fragment kolumny zwanej umbilicus urbis Romae lub „pępkiem świata”. W starożytności wypisano na niej odległości pomiędzy stolicą imperium a najważniejszymi miastami: Atenami, Kartaginą, Aleksandrią i Londinum (dzisiejszy Londyn).

76 Idee te narodziły się i rozwinęły nie tylko dzięki wspaniałości sanktuariów chrześcijańskich, lecz także jako odbicie Biblii i tradycji judeochrześcijańskiej.

77 Por. T. Krüger, Geschichtskonzepte im Ezechielbuch, s. 77.

78 Przepowiednie Sybilijskie zapowiadają, że odnowiona Jerozolima będzie nazwana „miastem Bożym pośrodku ziemi”; por. Oracula Sibillina 5, w. 250.

79 Dla Atanazego Księga Psalmów to jakby „rajski ogród”, który opiewa to, co opowiedziane jest w Piśmie Świętym i pokazuje to, co jest istotne w natchnionych księgach (por. Epistola ad Marcellinum 2). Według biskupa Aleksandrii Ps 74(73) należy do grupy natchnionych pieśni zawierających zarówno wyznanie, jak i narrację (por. tamże 14), jak i podziękowanie (tamże 15). Psałterz stanowił podsumowanie Pisma Świętego, R.E. Heine, Reading the Old Testament with the Ancient Church (Evangelical Ressourcement), s. 147.

80 Chodzi głównie o Mowy przeciwko arianom. Doskonałym przykładem egzegezy preferującej dosłowność tekstu jest komentarz do Ps 121, w którym jego autor opisuje Jerozolimę „zgodnie z historią” jako siedzibę królewską. Por. Expositio in Ps 121,5, PG 27, kol. 513 A.

81 Expositio in Ps 74, 12, PG 27, 336 C. U Atanazego nie brak innych wzmianek typu topograficznego, por. In Cantica (frag.) 3. 
Świętego miały miejsce w okolicach Jerozolimy ${ }^{82}$. Powyższe fakty, nawiązujące do „zstępowania” Boga na ziemię, są dowodem Jego dobroci ${ }^{83}$.

Nawiązanie do misterium krzyża pozwala biskupowi Jerozolimy - Cyrylowi na mówienie o Golgocie, jako środku ziemi, skąd Chrystus rozłożył ramiona w symbolicznym geście przygarnięcia całego rodzaju ludzkiego.

„[Chrystus] wyciągnął ręce na krzyżu, aby objąć nimi całą ziemię", pisze Cyryl. „Golgota bowiem jest środkiem ziemi. Nie jest to moja nauka. Prorok powiedział: «Dokonałeś zbawienia w środku ziemi» (Ps 74 [73],12). Wyciągnął swe ręce Ten, który swoimi duchowymi rękoma utwierdził niebiosa. Przebite one zostały gwoździami. Przez przybicie do krzyża i śmierć ludzkiej natury, obciążonej ludzkimi grzechami, równocześnie i grzech umarł, a w sprawiedliwości powstaliśmy z martwych" (por. Rz 6,6-8) ${ }^{84}$.

Świadectwo proroctwa ${ }^{85}$ służy Cyrylowi do potwierdzenia przekazu tradycji judeochrześcijańskiej, upatrującej w miejscu ukrzyżowania Chrystusa Pana także grobu praojca Adama. Myśl tę potwierdzają inni autorzy chrześcijańscy ${ }^{86}$. Dodatkowo dla chrześcijan Kalwaria była nowym „wzgórzem Moria”, miejscem, gdzie nastąpiło „związanie Izaaka” i ofiara Syna Bożego ${ }^{87}$.

Geograficzny wymiar zbawienia z podkreśleniem roli Golgoty uwydatniali autorzy antyariańscy. Niepoślednią rolę odgrywają tutaj elementy biblijne, jak w przypadku jednego z tekstów pseudoatanazjańskich: „To, że Chrystus został

82 „To tutaj Chrystus zstąpił z nieba, to tutaj Duch Święty zstąpił z niebios [na Apostołów]”; Catechesis XVI,4, PG 33, 924 A, s. 258. Podobnie tamże III,7; XVII,13.

83 Por. Catechesis X,3.

84 Catechesis XIII,28, PG 33, 805 B, BOK 14, s. 199-200. Zob. B. Bagatti, E. Testa (opr.), Corpus Scriptorum de Ecclesia Matre, t. 4: Gerusalemme. La Redenzione secondo la Tradizione biblica dei S. Padri, s. 69.

85 Według Atanazego z Aleksandrii „w Psalmach... wyśpiewuje się te sprawy, które zapowiada się w każdej z pozostałych ksiąg... Człowiek, który bierze tę księgę, przechodzi po kolei proroctwa odnoszące się do Zbawcy, które zazwyczaj podziwia się i czci w innych Pismach, a inne Psalmy odczytuje jako własne słowa. Słuchacz zaś jest poruszony jakby to on sam czytał i zestrojony jest ze słowami tych pieśni jakby to były jego własne słowa”; Epistola ad Marcellinum 8, 11, PG 27, 17 C i 21 C, s. 314 i 316.

86 Traktat przeciwko heretykowi Marcjonowi wspomina o pochówku Adama na Kalwarii czyli „w środku świata” (por. Carmen contra Marcionem). Podobnie wyraża się Epifaniusz z Salaminy, opisując wędrówkę Adama po wygnaniu z raju i jego pochówek u stóp Golgoty (por. Adversus haereses [Panarion] II,1,5). Według opinii przypisywanej Bazylemu Wielkiemu jest to „niepisana tradycja Kościoła” (por. In profetam Isaiam V,141).

87 Można dostrzec tutaj ogólny proces przejmowania przez chrześcijańskie sanktuaria tradycji biblijnej i judaistycznej. Jest tego przykładem Breviarius de Hierosolyma z VI wieku. 
ukrzyżowany pośrodku świata zostało napisane w Psalmie 73: «Bóg jednak od początku jest moim królem, pośrodku ziemi dokonał zbawienia» (Ps 74 $[73], 12)^{\prime \prime 88}$.

Dydym Ślepy nawiązuje do tej idei w sposób bardzo wyrazisty:

Dawid w Psalmie 73, wysławiając Przedwiecznego, głosi: „Bóg, nasz król, odwieczny, pośrodku ziemi dokonał zbawienia" (Ps 74[73],12). Ma na myśli tutaj Golgotę, miejsce najważniejsze i nazywa ją środkiem [obszaru] będącego pod niebem, gdzie według Boskiej wszechwiedzy Syn dokonał zbawienia przez swe wcielenie po wszystkie wieki. Bowiem, gdy Ten, który nie podlega zmianom dla nas umarł jak pragnął i chciał, co można określić: „przybył do środka ziemi”. W tym znaczeniu wypowiada proroctwo Ezechiel: „Umieściłem Jerozolimę między poganami” $(\operatorname{Ez} 5,5)^{89}$.

Akcentowanie warunków topograficznych stanie się z czasem normą w opisach pielgrzymów i ważnym elementem egzegezy ${ }^{90}$. W refleksji biblijnej Ojcowie Kościoła łączyli konkretne elementy geograficzne z symbolicznymi. Była to wspólna tradycja, silnie zaakcentowana przez św. Hieronima, ale obecna także $\mathrm{u}$ autorow wschodnich ${ }^{91}$.

Przekonanie o istnieniu środka świata, i to właśnie w Jerozolimie, było podparte autorytetem Pisma Świętego. Glosa autorstwa Hieronima zawarta w komentarzu do Ez jest bardzo znamienna, gdyż łączy Ps 74,12 i Ez 5,5 z konkretną rzeczywistością geograficzną ${ }^{92}$. Według Strydończyka całą Ziemię Świętą, a Jerozolimę w szczególności, cechuje niezwykły rys: to centrum duchowości

88 Pseudo-Atanazy, Quaestiones ad Antiochum 137,10, PG 28, 696 A, Por. B. Bagatti, E. Testa, Corpus Scriptorum de Ecclesia Matre, t. 4, s. 69.

89 Dydym Ślepy, De Trinitate I,15, PG 39, kol. 324 B-326 A. Zob. M.C. Paczkowski, Gerusalemme - „ombelico del mondo”, s. 184-185.

90 Psalmy były śpiewane w liturgii i podczas wędrówki grup pielgrzymów. Poświadczają to relacje Egerii i Grzegorza z Nyssy. Hieronim w swoich Listach mówił o miejscu Psalmów w pobożności chrześcijańskiej i w życiu monastycznym. Por. R.E. Heine, Reading the Old Testament with the Ancient Church (Evangelical Ressourcement). Exploring the Formation of Early Christian Thought, s. 145.

91 Z drugiej jednak strony idea Jerozolimy jako „środka świata” nie zawsze znajdywała zwolenników wśród przedstawicieli wyrafinowanej myśli teologicznej, czego klasycznym przykładem jest opinia Grzegorza z Nyssy. Przekonywał on, że świętość koncentruje się w Kościele jako wspólnocie i miejscach modlitwy chrześcijan. Nawet w Jerozolimie chrześcijańskiej nie ma takiego miejsca, które należałoby uważać za bardziej święte niż inne. Zmiana miejsca nie powoduje zbliżenia się ku Bogu, twierdził z całą otwartością Grzegorz. Por. Epistula 2,16.

92 Por. M.C. Paczkowski, Gerusalemme - „ombelico del mondo”, s. 187-190. 
i pobożności chrześcijańskiej. Wskazuje na to już samo położenie miasta Bożego ${ }^{93}$.

Jerozolima położona jest w środku świata. Poświadcza to sam prorok, ukazując, że jest ona pępkiem ziemi (Hierusalem in medio mundi sitam). Psalmista, opisując Narodzenie Pańskie mówi: „Prawda z ziemi wyrosła” (por. Ps 85,12) ${ }^{94}$. Natomiast opisując mękę [Chrystusa] rzecze: „Dokonałeś zbawienia w środku ziemi” (Ps 74[73],12). Rzeczywiście [Jerozolima] od wschodu otoczona jest obszarem nazywanym Azją; od zachodu [graniczy] z terytorium nazywanym Europą; od południa [przylega] do Libii i Afryki; a od północy [graniczy] z narodami Scytów, Armenii i Persji oraz z obszarem Pontu. Rzeczywiście leży pośrodku narodów, ponieważ sam Bóg narodził się w Judei i Jego imię było wielkie w Izraelu, aby wszystkie sąsiednie ludy szły za jej przykładem. Ona jednak naśladowała nieprawości narodów, które ją otaczały i przewyższyła je w swoich występkach. Pięknie zinterpretował to Symmach: „Oto jest Jerozolima, którą umieściłem między narodami i która w tych krajach zamieniła moje prawa z przewrotnością równą poganom..., ponieważ wzgardziła moimi prawami i nie postępowała według moich ustaw” (por. Ez 5,5-6)

Autor Wulgaty zastosował znany wzorzec interpretacyjny, według którego przepowiednie prorockie dotyczące Izraela należy odnosić do Kościoła - nowego ludu Bożego.

Wyciągnąłeś swoją rękę nad tymi, którzy byli opuszczeni, a następnie przywróceni [do łask], nad ludem, który został zgromadzony spośród wszystkich narodów ${ }^{96}$, który posiadł na własność i zamieszkał w środku ziemi (esse habitator umbilici terrae) ${ }^{97}$. O nim napisano: „[Bóg] dokonał zbawienia w środku ziemi” (Ps 74 $[73], 12)^{98}$.

93 Podobną kwestię porusza Tractatus in Ps. 106,3.

94 „Prawda” to jeden z podstawowych tytułów chrystologicznych.

95 Commentarii in Ezechielem II,5,5, ed. F. Glorie, CCL 75, Tornhout 1964, s. 56. Fragment ten przytacza Raban Maur w komentarzu do tej samej księgi prorockiej; por. PL 110, kol. 599.

96 Tłum. Ez 38,12 wg Wulgaty brzmi: „Super eos qui deserti fuerant et postea restituti et super populum qui est congregatus ex gentibus qui possidere coepit et esse habitator umbilici terrae". Tekst wg Biblia sacra iuxta Vulgatam versionem.

97 Teodoret z Cyru opisuje położenie Jerozolimy pośrodku kontynentów i nazywa ją „centrum świata”: „[Bóg] dał na zamieszkanie [Izraelowi] miejsce, które jest pępkiem świata. Od wschodu i północy znajduje się Azja, na zachód przez morze łączy się z Europą, na południu jest Libia. Masz więc trzy części ziemi, podzielonej między synów Noego"; Explanatio in Ezechielem II,5,5-6, PG 81, kol. 864 C. Jest to myśl rozwinięta przez żydowskie apokryfy.

98 Commentarii in Ezechielem XI,38, CCL 75, s. 526. 
Usytuowanie Judei i jej stolicy, zdaniem Strydończyka, ułatwiło głoszenie Bożych prawd w świecie ${ }^{99}$. Warto jednak zwrócić uwagę, że Hieronim otwiera w tym przypadku długą tradycję egzegetyczną, która opiera się na dosłownej interpretacji tekstu biblijnego, stanowiącej oparcie dla wzmianek o geografii palestyńskiej. Nie jest nowością przytaczanie różnych wersji przekładu Biblii ${ }^{100}$, co egzegeta $\mathrm{z}$ Betlejem czynił systematycznie w swoich komentarzach do tekstów prorockich ${ }^{101}$. Hieronim nie wystrzega się jednakże sprowadzania refleksji na tory rozważań o mysterium iniquitatis. Jerozolima, jako „środek świata”, w sposób niepodlegający dyskusji zawiera w sobie wszelką ludzką nieprawość ${ }^{102}$. Tak więc Chrystus, umierając w owym miejscu grzechu, nadał swej zbawczej śmierci większego dramatyzmu ${ }^{103}$.

To wyjaśnienie Hieronima odbiło się szerokim echem u późniejszych autorów łacińskich. Tego typu wskazówka znajduje się wśród zwięzłych wiadomości o miejscach świętych w Palestynie w dziele przypisywanym Eucheriuszowi ${ }^{104}$. Autor ten zaczerpnął dane topograficzne o Ziemi Świętej z dzieł Hieronima ${ }^{105}$. Inny z wpływowych autorów schyłku literatury patrystycznej - Izydor z Sewilli, podążał śladem biblijnych i patrystycznych wyjaśnień odnoszącymi się do Jerozolimy jako „środka ziemi” ${ }^{106}$. Jego wzmianki potwierdzają ugruntowanie się tradycji opierania na Ps 74(73),12 pojęcia „środka świata”. Dwa wieki później Izydora cytował Raban Maur ${ }^{107}$.

99 Przy innej okazji Hieronim wymienia Jerozolimę z innymi narodami; por. Epistula $18 \mathrm{~A}, 15$.

100 Tekst Iz 24,13 wg Wulgaty: „In medio terrae, in medio populorum” (w środku ziemi, pomiędzy narodami) w odczuciu Hieronima współgra ze wzmiankami o centralnym położeniu świętego miasta; por. In Ps 84; In Isaiam VIII,24,7;14.

101 Komentarze do ksiąg prorockich (Opus Prophetale), które ujrzały światło dzienne pod koniec jego życia, stanowią owoc wieloletnich poszukiwań egzegetycznych Strydończyka.

102 Por. B. Bagatti, E. Testa, Corpus Scriptorum de Ecclesia Matre, t. 4, s. 82, przyp. 60.

103 Wielu chrześcijan uważało, że z powodu ukrzyżowania Chrystusa Jerozolima została odrzucona. Hieronim uzasadnia upadek Jerozolimy tekstami prorockimi; por. In Isaiam XIII,50,1 (libellum repudii).

104 „Pośrodku Judei znajduje się miasto Jerozolima, jakby pępek całego [owego] obszaru (in medio autem Iudaeae civitas Hierusolima quasi umbilicus regionis totius)”, De situ Hierosolimitanae urbis 30, s. 134.

105 Chodzi tu o Epistula 129,4-5. Por. M.C. Paczkowski, Gerusalemme - „ombelico del mondo", s. 193.

106 Por. Etymologiae XIV,3,21.

107 De universo 12,4, PL 111, 339 C. 
Tekst przypisywany Piotrowi Diakonowi ukonkretnia teologiczny wątek Jerozolimy jako środka świata. Główną rolę odgrywa tutaj lokalizacja grobu Chrystusa i bazyliki Anastazis.

Grób Pański... wznosi się pośrodku świątyni. Świątynia zaś [znajduje się] pośrodku miasta ku północy, niedaleko od bramy Dawida. Za [miejscem] zmartwychwstania znajduje się ogród, w którym święta Maria [Magdalena] rozmawiała z Panem. $\mathrm{Z}$ tyłu poza kościołem oznaczono środek świata (foris ecclesiam retro est medietas orbis), o którym to miejscu mówi Dawid: «Bóg, nasz król, odwieczny, pośrodku ziemi dokonał zbawienia» (Ps 74[73],12). Inny prorok głosi ponadto: „Oto jest Jerozolima, którą umieściłem między narodami” (Ez 5,5)

Jak się wydaje, tekst ten podaje informacje niezależnie od Itinerarium pątniczki Egerii i relacji Bedy. Z pewnością to przekaz wcześniejszy, ale nie dotyczy okresu sprzed budowy bazyliki konstantyńskiej. W każdym razie widać już tendencję, by zlokalizować w punkcie geograficznym świadectwa, które wcześniej były w sferze rozważań teologicznych, a nie topograficznych ${ }^{109}$.

Od początków VII wieku można zauważyć, że ideę środka ziemi zaczęto oddzielać od Kalwarii i Anastazis. Szukano w Jerozolimie innych wskazówek, że miasto znajduje się „w środku świata”. Poświadcza to relacja Sofroniusza, patriarchy jerozolimskiego z okresu inwazji muzułmańskiej, opisującego w poetyckich wersach wygląd miejsc świętych przed zniszczeniem ich przez Persów w 604 roku. Według jego relacji omphalos został umieszczony w wydzielonej części bazyliki, aby nie przyćmiewać sławy wzgórza Golgoty i Jego chwalebnego grobu ${ }^{110}$.

Spisujący relację opata Arkulfa ${ }^{111}$, Adamnan z Hy w Szkocji wzmiankuje kolumnę przy dzisiejszej Bramie Damasceńskiej ${ }^{112}$, która

podczas letniego zrównania dnia z nocą, w południe, kiedy słońce przechodzi przez sam środek nieba, w cudowny sposób nie rzuca ona żadnego cienia... [Wtedy] oblana z góry blaskiem słonecznym i z każdej strony otoczona światłem, dowodzi, że Jerozolima położona jest w samym środku świata. Stąd, w odniesieniu do tych

108 De locis sanctis 1, ed. P. Geyer, CSEL 39, s. 107.

109 Por. B. Bagatti, E. Testa, Corpus Scriptorum de Ecclesia Matre, t. 4, s. 82, przyp. 62.

110 Pisze on: „Wejdę do tryportyku... / i ucałuję święty pępek ziemi, a na klęczkach kamień / gdzie stanęło owo drzewo [krzyża], / które zniweczyło klątwę drzewa [rajskiego]", Carmina anacreontica XX, PG 87, kol. 3817 B-3820 A. Por. M.C. Paczkowski, Gerusalemme - „ombelico del mondo”, s. 194.

111 Podróż Arkulfa odbyła się w 685 r.

112 Arabowie zwą ją dziś „Bab al-Amud”, czyli „Bramą Kolumny”. 
świętych miejsc męki i zmartwychwstania, które znajdują się w Aelii, śpiewa Psalmista: „Bóg pośrodku ziemi (in medio terrae) dokonał zbawienia” (Ps 74 [73],12); to znaczy w Jeruzalem, o którym mówi się, że [znajduje się] pośrodku ziemi i jest pępkiem świata (mediterranea et umbilicus terrae dicitur) ${ }^{113}$.

Manuskrypty z IX wieku, które przekazują opis podróży Arkulfa ilustruje między innymi schematyczne przedstawienie rotundy Anastazis. Zauważono ścisłą analogię pomiędzy tym szkicem a obrazem idealnego, niebiańskiego Jeruzalem ${ }^{114}$. Po traktacie Adammana odnośnik do Jerozolimy jako centrum świata nie pojawił się przez niemal cztery stulecia, aż do wypraw krzyżowych. Od XI wieku przedstawiano Jerozolimę jako środek świata ${ }^{115}$. Teksty średniowieczne, odnoszące się do pielgrzymek do Ziemi Świętej w ponad połowie przypadków wzmiankują ten fakt ${ }^{116}$. Na kanwie tradycji interpretacyjnej Ps 74(73),12 był postrzegany przez autorów średniowiecznych w szerszym kontekście ${ }^{117}$.

Wydawać by się mogło, że niewiele przesłanek przemawiało za tym, aby egzegeza Ps 74(73),12 obrała specyficzny kierunek związany z geografią i wskazaniem na Jerozolimę jako centrum świata. Soteriologiczne znaczenie zostało umocnione o wskazanie „miejsca” odkupienia. W odniesieniu do odkupienia dokonanego przez Chrystusa, wskazywano na rzeczywistość topograficzną i historyczną.

113 De locis sanctis I,11,2-4, s. 239-240, tłum. P. Iwaszkiewicz, Do Ziemi Świętej. Najstarsze opisy pielgrzymek do Ziemi Świętej (IV-VIII w.), s. 301-302. Zob. Por. M.C. Paczkowski, Gerusalemme - „ombelico del mondo”, s. 194.

114 Wskazują na to średniowieczne kodeksy, zawierające Ap.

115 Por. Sewulf, Peregrinatio ad Hierosolymam et T.S. 7. Począwszy od średniowiecza pielgrzymi przekazują informację, że środek ziemi zaznaczono w bazylice Grobu Świętego za pomocą okręgu, a następnie pokazywano wystający z posadzki niewielki okrągły kamień.

116 Por. I. Macleod Higgins, Defining the Earth's Center in a Medieval „multi-text”. Jerusalem in The Book of John Mandeville, s. 35.

117 Średniowieczny autor Julian z Vezelay mówi: „Chrystus stawszy się człowiekiem, przychodzi do ludzi jako ten, który stał się śmiertelny dla zbawienia śmiertelnych oraz [jako] ten, który przez swoją śmierć, wybawi zmarłych. Jako Pośrednik dokonał zbawienia pośrodku ziemi (Ps 74,12), podwyższony nad ziemię (J 12,32), pomiędzy niebem a ziemią, umarł na krzyżu, jako znak pojednania między niebiosami a ziemią"; Sermo 1, s. 53. 


\section{Bibliografia}

\section{Źródła}

Athanasius Alexandrinus (pseudo-), Quaestiones ad Antiochum, PG 28, kol. 597 C-708 D.

Athanasius Alexandrinus, Contra Arianos, PG 26, kol. 12 A-525 A.

Athanasius Alexandrinus, De titulis Psalmorum, PG 27, kol. 603 A-1343 A.

Athanasius Alexandrinus, Epistola ad Marcellinum, PG 27, kol. 12-45.

Azéma Y. (ed.), Théodoret de Cyr. Correspondance (1-95), t. 2, SCh 98, Paris 1964.

Banterle G. (ed.), Opere di San Pietro Crisologo, t. 1, Sermoni [1-62 bis] (Scrittori dell'Area Santambrosiana 1), Milano - Roma 1996.

Biblia sacra iuxta Vulgatam versionem (Vetus Testamentum), Roma 1986.

Braun R. (ed.), Opera Quodvultdeo Carthaginiensi episcopo tributa, CCL 60, Turnhout 1976.

Cassiodorus, In Psalterium expositio, PL 70, kol. 25 B-1056 C.

Daur K.D. (ed.), Arnobii Iunioris Commentarii in Psalmos, CCL 25, Tornhout 1990.

Doignon J. (ed.) Demeulenaere R. (intr.), Sancti Hilarii Pictaviensis Episcopi Tractatus super Psalmos: In psalmos CXIX-CL, CCL 61, Turnhout 2009.

Dydimus Alexandrinus, De Trinitate, PG 39, kol. 269 A-992 C.

Geyer P. (wyd.), Itinera Hierosolymitana saeculi III-VIII, CSEL 39, Vindobonae 1898.

Glorie F. (ed.), S. Hieronymi presbyteri opera, pars I,4: Opera exegetica. Commentariorum in Hiezechielem libri XIV, CCL 75, Turnhout 1964.

Hill R., Theodoret of Cyrus, Commentary on the Psalms 1-150, t. 1-2 (The Fathers of the Church 101-102), Washington D.C. 2000-2001.

Iwaszkiewicz P. (tłum.), Starowiejski M. (opr.), Do Ziemi Świętej. Najstarsze opisy pielgrzymek do Ziemi Świętej (IV-VIII w.), OŻ 13, Kraków 1996.

Jaeger W. (ed.), Gregorii Nysseni, Contra Eunomium liber III, w: id., Gregorii Nysseni Opera, t. 2, Leiden 1960.

Jordan D., Pseudo-Irenaeus Lugdunensis, Fragmenta varia (Texte und Untersuchungen zur Geschichte der altchristlichen Literatur 36,3), Leipzig -Berlin 1913.

Kania W. (tłum.), Św. Cyryl Jerozolimski. Katechezy przedchrzcielne i mistagogiczne, BOK 14, Kraków 2000.

Kubicki Wł. (tłum.), Salij J. (wstęp), Święty Augustyn, Państwo Boże (Biblioteka Europejska - Antyk), Kęty 2015.

Moreschini C. (ed.), Sant'Ambrogio, La fede (Opera Omnia di Sant'Ambrogio 15: Opere dogmatiche 1), Milano-Roma 1984

Moreschini C., Gallay P. (ed.), Grégoire de Nazianze, Discours 38-41, SCh 358, Paris 1990.

Mueller F. (ed.), Gregorii Nysseni Opera dogmatica minora, w: id., Gregorii Nysseni Opera, t. 3/1, Leiden 1958.

Origenes, Selecta in Psalmos, PG 12, kol. 1053 A-1685 A. 
Pismo Święte Starego i Nowego Testamentu, Poznań 2000.

Rabanus Maurus, Commentaria In Ezechielem, PL 110, kol. 497 C - 1084 C.

Rabanus Maurus, De Universo Libri XXII, PL111, kol. 9 - 0614 B.

Rousseau A., Doutreleau L. (ed.), Irénée de Lyon, Contre les hérésies, livre I, SCh 264, Paris 1979.

Sancti Aurelii Augustini Hipponensis Episcopi ad Marcellinum de civitae Dei contra Paganos, PL 41, kol. 13-804.

Sancti Aurelii Augustini Hipponensis Episcopi Enarrationes in Psalmos, PL 36, kol. 67-1027; PL 37, kol. 1033 - 1967.

Sedlacek I. (ed.), Dionysius bar Salibi, In Apocalypsim, CSCO 60, Paris 1913.

Sophronius Hierosolymitanus, Carmina anacreontica, PG 87, kol. 3733 A-3837 C.

Sulowski J. (tłum.), Stanula E. (oprac.), Św. Augustyn, Objaśnienia Psalmów, PSP 39, Warszawa 1986.

Theodoretus Cyrrhensis, Explanatio in Ezechielem, PG 81, kol. 807 A-1256 B.

Theodoretus Cyrrhensis, Interpretatio in Psalmos, PG 80, kol. 857-1998.

Tronina A. (wstęp i tłum.), Św. Atanazy, List do Marcelina o interpretacji Psalmów, Vox Patrum 8 (1990), s. 303-332.

Vorreux D. (ed.), Julien de Vézelay, Sermons 1-16, t. 1, SCh 192, Paris 1972.

Weber R. (ed.), Sancti Cypriani episcopi opera, pars 1, CCL 3, Turnhout 1972.

Zingerle A. (ed.), Hilarius Pictaviensis, Tractatus super psalmos, CSEL 22, Vindobonae 1891.

\section{Opracowania}

Bagatti B., Testa E. (opr.), Corpus Scriptorum de Ecclesia Matre, t. 4: Gerusalemme. La Redenzione secondo la Tradizione biblica dei S. Padri (Studium Biblicum Franciscanum - Collectio Maior 26) Jerusalem 1982.

Beeley Ch. A., The Early Christological Controversy: Apollinarius, Diodore, and Gregory Nazianzen, "Vigiliae Christianae" 65 (2011), s. 378-395.

Biblia patristica. Index des citations et allusions bibliques dans la littérature patristique, Paris 1995.

Böhl F., Über das Verhältnis von Shetija-Stein und Nabel del Welt in der Kosmogonie der Rabbinen, Die Welt des Orients 8 (1975), s. 77-90.

Bouteneff P.C., Beginnings Ancient Christian Readings of the Biblical Creation narratives, Grand Rapids 2008,

Di Berardino A. (red.), Nuovo Dizionario patristico e di antichità cristiane, t. 1, Genova-Milano 2006.

Fabre V., La Prophétie des Psaumes selon saint Augustin. A propos de Ps 1,1, "Nouvelle Revue Théologique" 4 (2006), t. 128, s. 546-560.

Forstner D., Świat symboliki chrześcijańskiej: Leksykon, Warszawa 2001, s. 57.

Grillmeier A., Christ in Christian Tradition, transl. J. Bowden, London 1965.

Heine R.E., Reading the Old Testament with the Ancient Church (Evangelical Ressourcement). Exploring the Formation of Early Christian Thought, Grand Rapids 2007. 
Kelly J.N.D., Początki doktryny chrześcijańskiej, tłum. J. Mrukówna, Warszawa 1988.

Krüger T., Geschichtskonzepte im Ezechielbuch (BZAW 180), Berlin 1989.

La Bonnardiere A.-M. (éd.), Saint Augustin et la Bible, Paris 1986.

Leanza S., L'esegesi di Arnobio il giovane al libro dei Salmi, "Vetera Christianorum" 8 (1971), s. 223-239.

Macleod Higgins I., Defining the Earth's Center in a Medieval „multi-text”. Jerusalem in The Book of John Mandeville, red. S. Tomasch, S. Gilles, Text and Territory. Geographical Imagination in the European Middle Ages, Philadelphia 1998, s. 29-53.

Müller H., Enarrationes in Psalmos, Philologische Aspekte, w: Augustinus-Lexicon, t. 2, fasc. 5/6 (2001), s. 806-807.

Paczkowski M.C., Gerusalemme - „ombelico del mondo” nella tradizione cristana antica, “Liber Annuus SBF” 55 (2005), s. 165-202.

Paczkowski M.C., Jerozolima jako „środek świata” w źródłach starochrześcijańskich, „Quaestiones Selectae” 19 (2005), s. 45-70.

Paszkiewicz P., Zadrożny T. (red.), Jerozolima w kulturze europejskiej, Warszawa 1997.

Peri V., Omelie origeniane sui Salmi. Contributo sull'identificazione del testo latino (Studi e testi 289), Città del Vaticano 1980.

Prinzivalli E., Gaio (e Alogi), NDPAC, t. 2, kol. 2029-2030.

Pyc M., Apolinaryzm w kontekście sporu o integralność człowieczeństwa Jezusa Chrystu$s a$, „Teologia w Polsce” 6/2 (2012) 5-16.

Quasten J., Patrologia, t. 2, Casale Monferrato 1983 [reprint].

Rondeau M.-J., Les commentaires patristiques du Psautier III ${ }^{e}-V^{e}$ siècles, t. 2 (Orientalia Christiana Analecta 220), Roma 1985. 